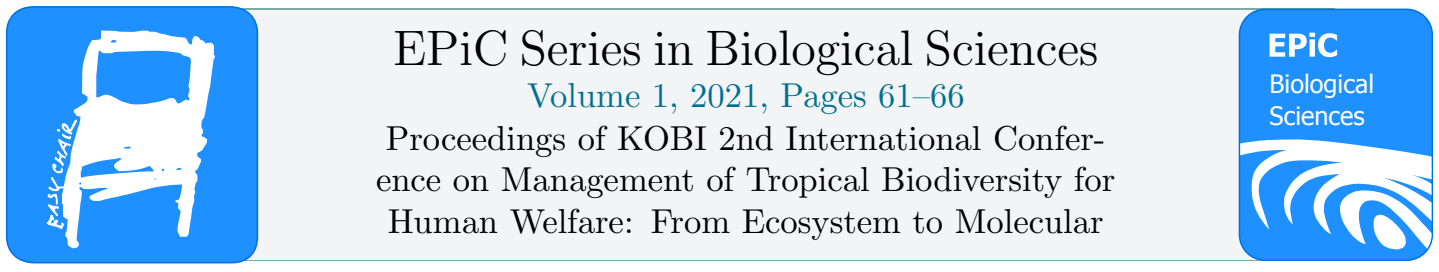

\title{
Stomatal Number and Size of Ornamental Dicotyledons Plant in Pontianak West Kalimantan
}

\author{
Lara Klarisya ${ }^{1}$ and Entin Daningsih ${ }^{1 *}$ \\ ${ }^{1}$ Universitas Tanjungpura, Pontianak, Indonesia \\ entin.daningsihefkip.untan.ac.id
}

\begin{abstract}
Greening in an urban area is a very important role in regulating temperature around. However, not all plants provide the same level of cooling. Cooling environmental temperature can be influenced by transpiration. This study aimed to measure the transpiration rate of dicotyledon plants. The method was a factorial Completely Randomized Design (CRD) with the main factors six dicotyledon species and three plant parts namely the top, middle, and bottom parts of the lowest plant branches with five replications. The data were analyzed using SAS. If the treatments were significant it was followed by the LSD test. The plant species and plant part significantly influenced the transpiration rate; however, the combination of the two did not significantly affect. The highest transpiration rate occurred significantly in Syzygium oleana R.Br $\left(0.013080 \mathrm{gr.cm}^{2}\right.$.hour $)$ whereas the lowest transpiration rate occurred in Codiaeum variegatum Bl. (0.004147 gr. $\mathrm{cm}^{2}$.hour). The bottom part of the plants $\left(0.009933 \mathrm{gr} . \mathrm{cm}^{2}\right.$.hour $)$ had the highest transpiration rate significantly compared to the middle $\left(0.009633 \mathrm{gr} . \mathrm{cm}^{2}\right.$.hour $)$ and the top $\left(0.007577 \mathrm{gr} . \mathrm{cm}^{2}\right.$.hour $)$. The highest transpiration rate in Syzygium oleana R.Br, as well as the bottom part of the plants, had the potential to reduce its surrounding temperature.
\end{abstract}

\section{Introduction}

Transpiration is the process of releasing water vapor from stomata present in the leaves (Kimball, 1983). Transpiration also aims to cool the plant's body through the cooling process by removing water vapor from the plant (Wang, 2015). The leaf mesophyll network has a very wide cell surface so that it can absorb $\mathrm{CO}_{2}$ efficiently. Environmental factors affect the opening and closing of the stomata on the leaf surface through which more than $90 \%$ of the water is transmitted. When the sun rises, the stomata open due to an increase of light and increases the temperature of the leaves so that the water evaporates 
faster. Rising temperatures make air capable of carrying more moisture, so transpiration increases and affects openings in the stomata (Ivan, 1980; SaIisbury and Cleon, 1995). Stomata can be found in leaves, flowers, and stems but the transpiration is more found in the leaves. The function of stomata is very important for transpiration. Rashed (2016) stated that the process of opening and closing of the stomata affecting transpiration.

The amount of water that is transmitted by plants is a typical event, although differences occur between one species and another species. The importance of transpiration for plants due to their role in helping to increase the rate of water transport and mineral salts, regulating plant body temperature by releasing heat excess from the body, and regulating optimum turgor in cells (Sasmitamihardja and Arbasyah, 1996).

Transpiration is only found in plants that have vessels. One of the vascular plants is angiosperms which are divided into two, namely monocotyledon and dicotyledon plants. There are several types of dicotyledon plants that are planted as ornamental plants in Pontianak. Green infrastructure (i.e. street trees, parks and gardens, green roofs, and walls) plays a very important role in regulating the surrounding temperature, especially during hot weather.

The other function of ornamental plants is to cool the environment, as revealed by Skelton et al. (2012) that one of the city greening solutions is shading plants. However, not all plants provide the same level of cooling effect. Transpiration can regulate the body temperature of the plant by releasing heat excess from the body. Transpiration occurs in different parts of the plant and varies between species. Transpiration is controlled by the opening and closing behavior of the stomata, where stomata behavior varies according to the type of the plant (Prijono, 2016).

This study aimed to measure the transpiration rate in some ornamental plants of dicotyledon and part of the plants. The six types of plants do not have cuticles because the cuticles can inhibit the process of transpiration (Bueno et al, 2019).

\section{Materials and Method}

The study was conducted at Biology Education Laboratory, Faculty of Teachers Training and Education, Tanjungpura University. This study used Factorial Completely Randomized Design (CRD) with the main factors namely two six plant species and three plant parts with five replications. The six plant species were Sambang dara (Excoecaria cochinchinensis Lour.), Bunga kertas (Bougainvillea spectabillis Willd.), Erpah (Aerva sanguinolenta B1.), Pucuk merah (Syzygium oleana R.Br.), Puring (Codiaeum variegatum $\mathrm{Bl}$.), dan Rombusa putih (Tabernaemontana corymbosa Roxb.). The three plant parts were the leaves from the top, middle, and bottom parts of the lowest branch of the plant. The combination was the plant species interacting with plant parts. The tools were scissors, $50 \mathrm{ml}$ Erlenmeyer, graduate cylinder, stopwatch, ruler, analytical balance, thermometer, lux meter, hygrometer, and wind speed meter. The materials used in this study were vaseline, water, clean cotton, labels, and six types of dicotyledonous plants.

The measurement was conducted between 09.00 and 11.00 am to facilitate the optimal opening of stomata (Fatonah, 2013). The transpiration rate was measured using the weight method (Leperen \& Medery, 1994). The initial weight included Erlenmeyer, water, leaves, cotton, and vaseline. The vaseline functioned as a cover of cotton to make airtight. Erlenmeyer which has been equipped with samples was exposed to sunlight for 30 minutes and then weighed again. The plants were exposed to the light for two times. The differences in weight between the final and initial weight indicating the water loss due to the transpiration. The transpiration rate was calculated using the formula as follows:

$$
\text { Transpiration rate }=\frac{\text { Final Weight }- \text { intial weight }(\mathrm{mg})}{\frac{\text { times }(\text { hour })}{\text { leaf area }\left(\mathrm{cm}^{2}\right)}}
$$


The leaf area was measured using the weight method. The leaf was patterned to the specific paper. The pattern was cut and weighed using an analytical balance. The leaf area was calculated using the following formula:

$$
\text { Leaf area }=\frac{\text { weight of pattern leaf }(\mathrm{gr})}{\text { weight of standard leaf }(\mathrm{gr})} \times \text { area of standard weight }\left(\mathrm{cm}^{2}\right)
$$

Data were analyzed by factorial CRD model using SAS. If the results showed a significantly different, then proceed with the Least Square Differences test (LSD) at $\alpha=0.05$.

\section{Results and Discussion}

The results showed the six plant species as well as plant parts affecting a significant transpiration rate (Table 1). The measurements of transpiration rate in used six dicotyledons species, namely Sambang dara (Excoecaria cochinchinensis Lour.), Bunga kertas (Bougainvillea spectabillis Willd.), Erpah (Aerva sanguinolenta Bl.), Pucuk merah (Syzygium oleana R.Br.), Puring (Codiaeum variegatum Bl.), and Rombusa putih (Tabernaemontana corymbosa Roxb.). The six types of plants are used as ornamental plants in the Pontianak city.

The main factors, namely plant species, and plant parts significantly influence the transpiration rate, but the combination of plant species and plant parts did not affect the transpiration rate (Table 1) The LSD test was conducted the significant result of variance analysis. Syzygium oleana R.Br. (Pucuk merah) was the highest transpiration rate $\left(0.013080 \mathrm{gr.cm}^{2}\right.$.hour $\left.{ }^{-1}\right)$ followed by Bougainvillea spectabillis Willd. (Bunga kertas) (Table 1). They were not significantly different from each other but Syzygium was different significantly to Aerva sanguinolenta Bl., Codiaeum variegatum Bl. (Puring), Excoecaria cochinchinensis Lour. (Sambang dara). However The transpiration rate of Bougainvillea spectabillis Willd. and Tabernaemontana corymbosa Roxb. Was similar to the transpiration rate of Aerva sanguinolenta Bl. $\left(0.010440{\mathrm{gr} . \mathrm{cm}^{2} . h o u r}^{-1}\right)$. Only the transpiration rate of Aerva sanguinolenta $\mathrm{Bl}$. was similar to that of Excoecaria cochinchinensis Lour. The lowest transpiration rate belonged to Codiaeum variegatum B1. which only similar to that of Excoecaria cochinchinensis Lour. but differ significantly with others. Different plant species influenced the transpiration rate. Transpiration rate is influenced by external and internal factors. External factors such as light, temperature, wind, relative humidity, and precipitation. The stomata opening depends upon light. As the light increase during the day, the stomata opening is more optimal. The optimal opening stomata occur between 09.00-11.00 am. The current research measurement was conducted within this time and the light measurement showed the same amount. Therefore, factors influencing the transpiration rate is not the light but the plant species. Other external factors such as wind speed, temperature, and relative humidity were also the same (data were not shown). The different transpiration rates due to internal factors such as the number of stomata per $\mathrm{cm}^{2}$, leaf thickness, water potential, and leaf morphology (Silva et al, 2014). The more stomata number in the leaf the quicker transpiration rate happened in the leaf. Other internal factors in the current research such as the number of stomata per $\mathrm{cm}^{2}$, the leaf thickness, water potential, and leaf morphology were not measured. However other studies conducted within the group research measured the stomata number and size. Leaf species according to the current research influenced the transpiration rate (Table 1). Prijono and Moh (2016) stated that transpiration was controlled by the behavior of the opening and closing of the stomata, where stomata behavior varied according to the plant species. De Wit et. al. (1961) stated that different transpiration amongst plant species due to different transpiration rates per unit leaf area. Different plant species have different leaf morphology. Syzygium oleana R.Br., Bougainvillea spectabillis Willd., Tabernaemontana corymbosa Roxb. have thin leaves that could contribute to transpiration rate. Further study needs to prove whether leaf thickness influences the transpiration rate. 


\begin{tabular}{|c|c|c|}
\hline Factors & $\begin{array}{r}\text { Mean } \\
\left(\mathrm{mg} / \mathrm{cm}^{2} / \mathrm{hr}\right) \\
\end{array}$ & Significancy \\
\hline Main Factor & & $* * * ¥$ \\
\hline \multicolumn{3}{|l|}{ Plants Species } \\
\hline Syzygium oleana $\mathrm{R} . \mathrm{Bx}$ & $0.013080^{\mathrm{a}}$ & \\
\hline Bougainvillea spectabillis Willd. & $0.011613^{\mathrm{ab}}$ & \\
\hline Tabernaemontana corymbosa Roxb. & $0.009907^{\mathrm{ab}}$ & \\
\hline Aerva sanguinolenta $\mathrm{Bl}$. & $0.009093^{\mathrm{bc}}$ & \\
\hline Excoecaria cochinchinensis Lour. & $0.006447^{\mathrm{cd}}$ & \\
\hline Codiaeum variegatum $\mathrm{Bl}$. & $0.004147^{\mathrm{d}}$ & \\
\hline Plants parts & & $*$ \\
\hline The bottom part & $0.009933^{\mathrm{a}}$ & \\
\hline The middle part & $0.009633^{\mathrm{ab}}$ & \\
\hline The top part & $0.007577^{\mathrm{b}}$ & \\
\hline Combination factors between plant species and plant parts & & ns \\
\hline \multicolumn{3}{|l|}{ Combination of leaf parts and plant species } \\
\hline Top - Aerva sanguinolenta $\mathrm{Bl}$. & 0.007820 & \\
\hline Top - Bougainvillea spectabillis Willd. & 0.012160 & \\
\hline Top - Codiaeum variegatum $\mathrm{Bl}$. & 0.001860 & \\
\hline Top - Excoecaria cochinchinensis Lour. & 0.001040 & \\
\hline Top - Syzygium oleana R.Br. & 0.013040 & \\
\hline Top - Tabernaemontana corymbosa Roxb. & 0.009540 & \\
\hline Middle - Aerva sanguinolenta $\mathrm{B} 1$. & 0.010440 & \\
\hline Middle - Bougainvillea spectabillis Willd. & 0.008440 & \\
\hline Middle - Codiaeum variegatum $\mathrm{Bl}$. & 0.005820 & \\
\hline Middle - Excoecaria cochinchinensis Lour. & 0.010740 & \\
\hline Middle - Syzygium oleana $\mathrm{RBr}$ & 0.015480 & \\
\hline Middle - Tabernaemontana corymbosa Roxb. & 0.006880 & \\
\hline Bottom - Aerva sanguinolenta $\mathrm{B} 1$. & 0.009020 & \\
\hline Bottom - Bougainvillea spectabillis Willd. & 0.014240 & \\
\hline Bottom - Codiaeum variegatum $\mathrm{B}$. & 0.004760 & \\
\hline Bottom - Excoecaria cochinchinensis Lour. & 0.007560 & \\
\hline Bottom - Syzygium oleana R.Br. & 0.010720 & \\
\hline Bottom - Tabernaemontana corymbosa Roxb. & 0.013300 & \\
\hline
\end{tabular}

Table 1: Results of variance analysis of transpiration rates from dicotyledon plants affecting by plant

Legends: species and plant parts using factorial CRD.

¥: ns = non-significant, $*=$ significant, $* * *=$ very significant when tested using ANOVA. The different letters behind the mean in the same column for each factor indicated the significance of the LSD test at $\alpha=0.05$.

The other main factor was plant parts namely the top part, the middle part, and the bottom part of the lowest branch of the plants. The transpiration rate from the leaf in the bottom part $(0.009933$ gr. $\mathrm{cm}^{2}$.hour $\left.{ }^{-1}\right)$ of the plant was the highest significantly compared to that of the top $(0.007577$ gr. $\mathrm{cm}^{2}$.hour $\left.{ }^{-1}\right)$ but similar to that of the middle part of the plant $\left(0.009633{\mathrm{gr} . \mathrm{cm}^{2} \text {.hour }}^{-1}\right)$ (Table 1$)$. The leaf in the bottom part of the plant is more mature than the other two positions. As the leaf develops the leaf size is wider (Yudha et al, 2013) and the stomata opening is getting bigger.

The combination of plant species and plant parts did not influence the transpiration rate (Table 1). Siahpoosh and Dehghanian (2014) stated that transpiration is influenced by the environment. These environmental factors were temperature, humidity, light intensity, and wind speed (Mahajan, 2008). And in this research, those external factors were the same (data were not shown). This research showed Syzygium oleana R.Bx (Pucuk merah) had the highest transpiration rate indicating the plant is not only ornamental but also capable to reduce temperature due to the high transpiration rate. 


\section{References}

AbdulRahaman AA and Oladele FA. (2003). Stomatal complex types, size, density and index in some vegetable species in Nigeria. Nigerian Journal of Botany, 16: 144-150

Al S, Suryani D, and Ratnawati. (2003). Tanggapan Stomata dan Laju Transpirasi Daun Vaccinium varingiaefolium (B1.) Miq menurut ingkat Perkembangan Daun dan Jarak terhadap Sumber Emisi Gas Belerang Kawah Sikidang Dataran Tinggi Dieng. In Bahasa. Seminar Hasil Penelitian MIPA, FMIPA $U N Y$.

Bange GGJ. (1953). On the quantitative explanation of stomatal Transpiration, Acta Botanica Neerlandica. 2: 256-297.

Bueno A, Ahmed A, Katja A, Markus B. et al.. (2019). Effects of temperature on the cuticular transpiration barrier of two desert plants with water-spender and water-saver strategies, Journal of Experimental Botany. 70(5): 1613-1625.

Condon AC, Farquhar A, and Richards RA. (1990). Genotypic Variation in Carbon Isotope Discrimination and Transpiration Efficiency in Wheat. Leaf Gas Exchange and Whole Plant Studies, Plant Physiol. 17: 9-22.

De Wit CT and Alberda TH. (1961). Transpiration coefficient and transpiration rate of three-grain species in growth chambers, Mededeling. 73-81.

Domínguez E, Jose A, Heredia G, and Antonio H. (2017). The plant cuticle: old challenges, new perspectives, Journal of Experimental Botany, 68(19): 5251-5255.

Fatonah S, Dwijowati A, Desi M, and Dyah, I, (2013). Penentuan Waktu Pembukaan Stomata pada Gulma Melastoma malabathricum L. Di Perkebunan Gambir Kapar. In Bahasa. Jurnal Biospecies, 6(2), $15-22$.

Ivan and Robin D. (1980). Revised Nuffield Biology: Text 2 Living Things in Action. London: Great Britain.

Kimball JW. (1983). Biologi Jilid 2 Edisi kelima. In Bahasa. Jakarta: Erlangga.

Leperen Van M. and Medery H. (1994). A new method to measure plant water uptake and transpiration simultaneously. Journal of Experimental Botany, 45(270): 51-60.

Mahajan PV, Oliveira FAR, and Macedo I. (2008). Effect of temperature and humidity on the transpiration rate of the whole mushrooms, Journal of Food Engineering, 84: 281-288.

Rashed RU. (2016). Substrate Effects on Plant Transpiration Rate under Several Vapour Pressure Deficit (VPD) Levels, Journal of Plant Pathology \& Microbiology, 7: 7.

Royer DL. (2001). Stomatal density and stomatal index as indicators of paleo atmospheric $\mathrm{CO}_{2}$ concentration. Review Palaeobotany and Palynology, 144(1-2): 1-28.

Papuangan. (2014). Jumlah dan Distribusi Stomata pada Tanaman Penghijauan di Kota Ternate. In Bahasa. Jurnal Bioedukasi, 3(1): 287-292.

Prijono S and Moh T. (2016). Studi Laju Transpirasi Peltophorum dassyrachis dan Gliricidia sepium pada Sistem Budidaya Tanaman Pagar serta Pengaruhnya terhadap Konduktivitas Hidrolik Tidak Jenuh. In Bahasa. Jurnal PAL, 7(1): 15-24.

Salisbury FB and Cleon WR. (1995). Fisiologi Tumbuhan Jilid 1. In Bahasa. Bandung: ITB.

Sasmitamihardja D and Arbasyah S. (1996). Fisiologi Tumbuhan. In Bahasa. Bandung: DEPDIKBUD.

Siahpoosh MR and Ebrahim D. (2014). Water Use Efficiency, Transpiration Efficiency, and Uptake Efficiency of Wheat during Drought. Agronomy Journal. 104(5): 1238-1243.

Skelton RP, Midgley JJ, Nyaga JM, Johnson SD, and Cramer MD. (2012). Is leaf pubescence of Cape Proteaceae a xeromorphic or radiation-protective trait. Australian Journal of Botany. 60: 104.

Spence RD, Wu H, Spharre PJH, and Clark G. (1986). Water stress effects on guard cell anatomy and the mechanical advantage of the epidermal cells. Plant, Cell \& Environment, 9(3): 197-202.

Spence RD. (1987). The problem of variability in stomatal responses, particularly aperture variance, to environmental and experimental conditions, New Phytologist, 107(2): 303-315. 
Vaz Monteiro M, Blanusa T, and Verhoef A. (2016). Relative importance of transpiration rate and leaf morphological traits for the regulation of leaf temperature, Australian Journal of Botany, 64(1): $32-44$.

Wang Y, Cheng X, and Xiang CB. (2007). Stomatal density and bio-water saving. Journal of Integrative Plant Biology, 49(10): 1435-1444.

Wang Q and Jia J. (2015). Leaf Transpiration of Drought Tolerant Plant can be Captured by Hyperspectral Reflectance using PLSR Analysis, 9: 30-37.

Yudha GP, Noli, ZA, and Idris M. (2013). Pertumbuhan Daun Angsana (Pterocarpus indicus Willd) dan Akumulasi Logam Timbal (Pb). In Bahasa. Jurnal Biologi Universitas Andalas, 2(2): 83-89. 